\title{
Displaced Children and the Violence of Humanitarianism in Cold War Italy
}

\section{Stavroula Pipyrou}

In early 1950s Calabria, South Italy, thousands of children were displaced as a consequence of severe flooding. Under the banner of humanitarianism, children were relocated by the political left and center-right to live with communist families in the north of Italy or to reside in summer camps and Church institutions. For the left, the humanitarian initiative was framed in terms of solidarity and a vision of the future based on close-knit family and party ties. For the centre-right, the humanitarian effort demonstrated "the caring state" and Catholic charity in action. Today, the events of the 1950s are shrouded in an interwoven veil of structural and embodied silence. From national historiography, through societal absence, to personal struggles with the traumatic past, the displaced children inhabit silence as a space in the world. This silence must be analyzed within the context of Cold War politics, the sedimenting of post-war collective consciousness, and the race between the left and center-right to claim the future generation of Italian citizens.

\section{Keywords: Silence; Cold War; Displacement; Children; Humanitarianism; Italy}

Maria's home feels so familiar. A large terracotta-rendered building with high ceilings, the entire house is flooded with light from the Calabrian sun. During the day the double-doors leading to Maria's veranda which overlooks a small plot of land dedicated to her beloved cactuses and with views to the glistening sea beyond are left wide open, allowing sweet drafts to drift from room to room. The furniture is instilled with family history and personal narratives. Portrait photographs adorn almost every wall; by now I have an intimate 
relationship with Maria's relatives, dead and alive. We often spend hours flicking through photo albums, reconstructing events that have touched the family and the wider community. Emotions, memories, and meaning-making entwine each time we huddle around an open album.

Photographs are central to Maria's life. Pictures of Maria's son who died suddenly twenty years ago are displayed throughout the home - when he was a new-born in his father's arms, with his brother on matching bicycles, as a teenager having fun with friends, at a family gathering the day before he died. Next to one of his portraits hangs a picture of an African girl. On the sideboard stands another picture of a group of young African children stood in front of a small concrete building. Maria introduces the girl as part of her family, her "adopted" daughter. In memory of their son, Maria and her husband Nino have funded the construction of a classroom in a small village in Western Africa and have undertaken a life-long commitment to sponsor a girl called Alicia. Although now in their 70s, Maria and Nino hope that they can one day meet Alicia, but for the time being they are happy to receive regular pictures and updates of her growing-up. Maria worries that Alicia's family might decide to migrate to Europe and join the swathes of people attempting the treacherous journey across the Mediterranean Sea. Highly reflexive on the unfolding humanitarian crisis playing out on Mediterranean shores, Maria's family is heavily engaged in raising awareness in the local community, working with the local priest to try to collect funds and activate support networks to assist migrants arriving in Calabria.

In a sense, Maria is a migrant herself having experienced multiple cases of movement. She now lives in a small village on the Ionian coast, part of the area Grecanica which is well known as the home of the Greek linguistic minority of Calabria (Pipyrou 2016a). Her village of origin, 
a thirty-minute drive into the Aspromonte mountains, lies semi-abandoned and features in Vito Teti's (2004) Il Senso dei Luoghi: Memoria e Storia dei Paesi Abbandonati. In Teti's study of le rovine (the ruins), the abandoned villages of Calabria stand as representations of humanity, dancing back and forth between "progress" and "decadence" (2004:14). Eerie, empty, and bone-chillingly cold, the majority of the abandoned houses in Maria's ancestral village are littered with traces of their last human occupants - pictures on walls cling precariously to rusty nails, dusty tables are expectantly set for food that was never served, wardrobes overflow with moth-eaten shirts, beds made, books stacked, pots on the stove. A step inside an abandoned home has to be well-calculated as floorboards creak and wooden staircases show signs of hungry termites. The streets are narrow and the collapsing walls only accentuate their labyrinthine feel. On occasion the presence of a careless cat adds an ironic touch of life. On the outskirts of the village a ramshackle set of dilapidated buildings are home to a group of twentyfour North African immigrants (fourteen adults and ten children), placed there without running water, a shop, or neighbors, to fend for themselves. Abandoned village, abandoned people. When Maria first found out that immigrants had been housed in her ancestral village she went to visit them. They showed her tenerezza (tenderness). They told her "signora, come back to see us when you want".

Maria holds a deep pain from her childhood and, poignantly, it was from this village in Aspromonte that she commenced the most important, affective, traumatic, movement of her life. This article tells the stories of people like Maria, stories that are absent from official histories of Italy and Europe, stories that are silenced in Calabrian communities. The events took place at the beginning of the 1950s when the province of Reggio Calabria was hit by catastrophic floods and landslides that rampaged through the region and left thousands of people homeless. Locals were evacuated by the Christian-Democrat government to refugee 
camps outside of Calabria. Like many of my research participants, Maria sees striking similarities between the Calabrian displacement and the current plight of African migrants with whom she empathizes deeply. People like Maria lived in summer camps, military bases and in Church-sponsored institutions while awaiting the reconstruction of their homes and infrastructure in their Calabrian villages (Pipyrou 2016a:36-39). During the same period, thousands of children were moved by civic groups associated with both the Communist Party and the Christian-Democrat government to be "saved" from the consequences of natural disasters. Maria and her brother Giovanni were two such children displaced by government humanitarian efforts after the alluvione (floods and landslides) of 1953, separated from their parents and each other to live in Church-sponsored institutions outside of Calabria. Maria is anxious that the story of African migrants might be as silenced as her own, that their traces will be lost in the historical archive. Maria is not alone in voicing her disbelief in both the Italian welfare system and how critical events reach, or not, the pages of history. Without exception, all my research participants draw critical comparisons between the 1950s Calabrian displacement, their pain and shame, and the migration crisis currently unfolding on Mediterranean shores. Maria's voice is representative of deep anxiety expressed in the local community about taking responsibility for displaced people.

Having escaped detailed historical, political and academic attention, the alluvioni of 1951 and 1953 and the subsequent evacuation of populations from the Ionian coast to various places around Italy (including Sicily, Lombardy, Lazio, and Abruzzo) have become emblematic of a "silenced" history that haunts local imagination. The history is silenced not in the sense that people do not remember or do not evaluate these events. Rather, the alluvioni and evacuations are only discussed on rare occasions among very close friends, and then only after much probing. Often inhabitants of the same small coastal village claim to be unaware of which 
fellow-villagers were relocated. The events of 1951 and 1953 are not reported in a systematic manner and are absent from official history because, I maintain, there was no space for their existence in the newly united Italian collective post-war imagination. Importantly, given the current political climate in Europe, silences that became manifest after World War II continue to influence how people talk (or not) about displaced people. Tara Zahra (2011:20) notes that "the resettlement of refugees and displaced persons after World War II ultimately represented a foundational moment in the development of postwar European migration policies". The postwar period was fundamental in giving birth to and establishing state and suprastate policies concerning displacement, spawning lasting ideological positions ultimately shaping the manner that particular thinking about migration is filtered down to everyday people.

In Cold War Italy silences are inextricably linked to the sedimenting of post-war collective consciousness and the race between the left and right to lay ideological claim to the future generation of Italian citizens. In the case at hand, silence results from well-meaning yet profoundly violent humanitarian interventions premised on care for children. Humanitarianism can operate as a form of violence, as Ticktin $(2006,2011)$ has argued, resulting in trauma and structural and individual silences.

If silence should be thought of as fundamental in shaping political subjectivities, then as anthropologists we have to find ways to evaluate it. I argue that there are two overarching types of silence at play that constantly intersect - structural silence at the level of official History where events go unrecorded, and embodied silences manifested in people's personal struggles with their traumatic experiences. The structural silence is apparent in both Italian historiography and as part of local sociality where for seventy years the relocations have rarely been deemed an appropriate topic of discussion. The embodied silence is an existential 
condition, a space in the world where people have learned to foster their relationship with the past.

The subject of a three-year Leverhulme Trust project and in the context of 15 years of anthropological research in the region, the material presented here is the outcome of meticulous ethnographic fieldwork in the Province of Reggio Calabria and extensive archival research in Reggio Calabria and Rome. I consulted the archives of the Centro Italiano Femminile (Italian Women's Center [CIF]), Unione delle Donne Italiane (Union of Italian Women, [UDI]), and the Archivio di Stato in Reggio Calabria and UDI and the Italian Communist Party (PCI) in Rome, as well as numerous private collections in cities across Italy. Further, I consistently attempted to trace the UDI list of names of children displaced from Reggio Calabria which has attained mythological status. Despite feeling I was getting close on multiple occasions the official list still remains out of reach - a central figure in the UDI-organized relocations motioned that the documents have been lost or destroyed.

The material found in the Archivio di Stato is not only fragmented but also regularly contradicts the ethnographic data and first-hand narratives of those displaced. These inconsistencies also include occasions when people I interviewed cited names of others who resided at the same institutions but who were not included on the official lists. On other occasions, the organizations responsible for the relocations denied that certain individuals were ever moved. The complexities of the archive, I have decided, cannot be adequately covered in this article since my aim here is to foreground the narratives of the people themselves, providing space for the nuances of their stories in an episode yet to be addressed from an anthropological perspective. An abridged attempt to explain the place of archives in the personal stories presented here would do an injustice to both the relocated children and the intricacies of the 
archive. Primarily through rich ethnographic material, in what follows I wish to highlight the clearly identifiable conditions and manifestations of silence that continue to overlap and intersect in the complexities of daily life for people displaced in 1950s Calabria.

\section{Children on the Move: Post-War Humanitarianism in Context}

Humanitarianism, Didier Fassin (2010:ix) suggests, is a "relatively recent invention" associated with the "global play of succor" and public celebration of generosity in coming to the assistance of victims of natural and human catastrophes over the past three decades (also de Waal 1997). Often intrinsically linked to military intervention, humanitarianism has become a potent global force of government of the precarious based on the pretence of a shared human condition. For Fassin (2010:1), "humanitarian government" denotes the "deployment of moral sentiments in contemporary politics" where the intolerances and injustices of the world are made somewhat bearable. However, Fassin (2010:4) notes that the politics that link compassion and the justification for governmental modes of population management have a deeper history that brings together the interplay between states, nongovernmental bodies, international and national organizations and local communities.

Indeed, the historical roots of humanitarianism are widely debated. Historical sociologist Rosemary Fitzgerald (2001), for example, employs data from India to trace humanitarianism to British and American missionary activity in the $19^{\text {th }}$ century, while historian Thomas Haskell (1985) focuses on the role of capitalism in fuelling humanitarian activity in the slavery abolition movement of the $18^{\text {th }}$ and $19^{\text {th }}$ centuries. Modern American humanitarianism, Kevin Rozario (2003) argues, is directly associated with the development of American reactions to suffering in the early twentieth century and the wide-scale creation "of a sensationalistic mass culture" to counter "compassion fatigue". This article stands as a contribution to these longer- 
term temporalities of humanitarianism in a context, Italy, where histories of the violence of humanitarianism remain silenced. Further, the regular coupling of humanitarianism with military intervention and inter-state relations have left discussions of other forms of assistance and the social dynamics that accompany them relatively unexplored (Mosse 2005:5, Minn 2007).

In the Italian context, Silvia Salvatici (2018:959) argues that instead of blindly accepting the growing trend to consider humanitarianism as a new phenomenon linked to the aftermath of international warfare since the 1990s, we should consider its longer political genealogy in more localized settings. This is not to deny overlapping humanitarian and military agendas that share the "temporality of emergency" and disregard sovereignty in the name of moral order that have proliferated in the last thirty years (Fassin and Pandolfi 2010:15, Fassin 2010:5, 241). Rather, Salvatici suggests, approaching humanitarianism as something new - and primarily linked to military action - siphons one toward an incomplete and narrow understanding of aid and welfare initiatives that have their roots in the $19^{\text {th }}$ century and expanded rapidly after World War II.

The doctrine of humanitarianism began to make inroads into European politics in the mideighteenth century, but it was after World War II that humanitarianism "went global" (Barnett 2011:49-50, 118). In Italy, questions of 'good government' and specifically humanitarianism - inextricably related to the development of a strong welfare system - have permeated politics since the Enlightenment. Risorgimento governments attempted to materialize Camillo Cavour's dream of reinforcing the social edifice rather than introducing radical reforms. For this reason, the approach of social intervention and social insurance was clearly defined as a "humanitarian" problem rather than one of "rights" (Quine 2002:26-31). 
Carl Ipsen argues that child welfare issues in Italy emerged in the period 1895-1910 as a direct result of an important "thrust in child philanthropy and child saving" in the West (2006:5). After much parliamentary debate, the child labour law known as the 'Berti Law' was passed in 1886. The law was deemed 'inadequate' but deputies voted in favor as there was no viable alternative. The Socialist Antonio Maffi, for instance, voted in support of this "humanitarian principle" (principio umanitario) (Ipsen 2006:107). The pre-World War I Giolittian regime did not introduce a systematic child welfare program. In 1907 Giolliti declared in parliament that "I hope that with the progress of civilization ... this humanitarian question will be resolved" (Quine 2002:226). In 1925 the fascist government introduced the Opera Nazionale per la Protezione della Maternità e dell'Infanzia (ONMI) which involved a series of public institutions of beneficence catering for women and children. This project, based on racial principles, was "one of the most important political, economic, eugenic and demographic priorities of Italy" (Lo Monaco-Aprile 1927:26 in Quine 137). After World War II, the Ente Nazionale per la Protezione Morale del Fanciulo, who were primarily responsible for the 1950s Reggio Calabria child displacements, regularly collaborated with ONMI, which was dissolved in 1975.

With Europe currently at the center of intense media attention and political debate about the mass movement of people from circa-Mediterranean conflict zones, more than ever we require detailed studies of the lived consequences of displacement that locate humanitarianism in longer-term social and historical frameworks. For instance, studies provided by scholars such as Gerard Daniel Cohen (2012) and Tara Zahra (2011) reveal how the complex realities of current displacement as a political question were shaped by post-World War II and Cold War agendas. It is only through a meticulous evaluation of historically-built silences that we can 
appreciate the political depth of the current narrative of mass displacement that is often termed "unprecedented"i Within Europe one can discover an array of silenced stories of displacement that, much like Maria's, regularly fail to make the pages of high school history textbooks and certainly rarely find a home in public awareness of migration and movement. ${ }^{\mathrm{ii}}$

The end of World War II found thousands of people displaced, caught between real politic, humanitarianism and a simplification of the refugee experience (Cohen 2011). These anonymous groups, "objects of policy rather than subjects of history", were treated as passive pawns of military and humanitarian governance: a "refugee nation" in need of help, desperate to return home (Cohen 2011:6-7, Gatrell 2011). For post-war nation-states, "care now meant providing for a stationary population that would hopefully soon be repatriated, while control meant ensuring that displaced persons did not become a threat to 'law and order"' (Holian, 2011:29). Children, the "quintessential victims of war" (Zahra 2011:24), rapidly embodied the political interests of competing ideologies and nations. Silent children became the physical embodiment of the challenge of regenerating Europe, not least its new national ambiguities and expectations (Zahra 2011:201, Lynch 2016:3). The end of World War II and the subsequent Cold War decades saw eager "child-savers" organized in new humanitarian movements promoting child welfare (see Gatrell 2013). As was the case in Italy, regardless of political and ideological positioning - Catholic or Communist -, child-related activism was linked to democracy, the state and family and a universal commitment to "the human" (cf. Ticktin 2011:3-5, Fassin 2010). While not exactly in agreement as to what this universal platform of "humanity" entailed, Western Christian leaders and anti-communists tended to "define the evils of totalitarianism specifically in terms of its alleged destruction of the family" (Zahra 2011:17).

It might thus seem ironic that in the Calabrian case of post-war displacement, children relocated by the left were sent to live with other families around Italy. The Communists prioritized the 
maintenance of family structure as the most productive way of nurturing the next generation of Italian citizens. For the left, the humanitarian initiative was framed in terms of solidarity and a vision of the future based on close-knit family and party ties. Extending the trope of family beyond the boundary of the home, the communist relocations were intended to demonstrate that the party took care of its children, promising an Italy reborn in working class solidarity. Through journals such as L'Unità and Noi Donne, the Communists claimed that the ChristianDemocrats (DC) failed to properly provide for the displaced children, accusing the DC of neglecting their duty of care; stories of children housed in Church institutions were accompanied by pictures of mothers coming to collect their suffering offspring. On the other hand, the Christian-Democrat humanitarian effort centered on a rhetoric of "the caring state" that was able to embrace all Italian citizens. Through outlets such as the Church journal L'avvenire di Calabria, DC members insisted that there was no need for fanfare as their rescue mission was based on generosity (bontà) and charity (carità) (L'Avvenire $5^{\text {th }}$ January 1952), the core attributes of the Catholic Church and desirable characteristics for future Italian citizens.

In Italy and across Europe, in the decade following the War children were objects of population politics, nation building projects, and new forms of humanitarian intervention in the midtwentieth century, as they represented the biological and political future of national communities as "fantasies of postwar reinvention were projected onto Europe's children" (Zahra 2011:20). "They must have all wanted to save us", Maria reflects, "although I don't remember many families (in the village) being particularly political, I am astonished to now find that the Communists and the Church were both interested in relocating children". The race to shape the ideological belonging of future generations had truly begun and the stakes were high. 
"As they struggled to restore stability to Europe's displaced families, Europeans simultaneously crafted competing visions for the reconstruction of European democracy, and articulated Cold War ideologies that would define Europe for the next fifty years. They developed new theories of human development, the nature of emotional bonds within the family, and the value of familial and collective education. They aimed, above all, to reshape the confused identities of children in their own images. The campaign to rehabilitate Europe's lost children was at once an effort to define the legacy of the Nazi past and a bid to control the shape of Europe's future" (Zahra 2011:22-23).

During the processing of child refugees in the post-war period, children were silent entities in a wider political game and any narratives that did not fit neatly with political goals were struck from the history books. The divisive events filled with ambivalence and shame did not fit the blueprint of "the memorable past" and these "anomalies" were structurally pushed out of history books and community accounts of the past (Winichakul 2002:246). As Thongchai Winichakul remarks in his account of a Thai massacre in 1976, decades later traumatic historical events remain unresolved for both individuals and society; there is still no coming to terms with a silenced, incomprehensible past. In the Italian context the structural silence also plays into tropes of hegemony and the marginalization of the South by the North, the so-called “Southern Question" (Schneider 1998, Moe 2006, Pipyrou 2014). The South, it is felt among many of my research participants, is ignored and written-out of "Italian" history and politics.

The Calabrian case is illustrative of how post-war refugee relocation initiatives, or what Fassin (2010) might term "humanitarian government", were packaged with a rhetoric of responsibility for care, yet the assimilation process was inertly violent. The children's life-stories encompassed feelings of shame, discomfort and deep trauma, with silenced stories pushed 
further into the personal and collective darkness. As Jacqueline Bhabha (2014:208) reflects, "wars, famines, and natural disasters have almost always resulted in the separation of children from their families" tearing up the social fabric of those they torment.

I argue that humanitarian initiatives after World War II were inherently violent and continue to be shrouded in multiple interrelated layers of silence; humanitarian assistance, in particular is often accompanied by social processes that are dehistoricizing, Liisa Malkki (1995) has argued, where textual or narrative representation is avoided with actions reported as unrelated to larger historical events. More detailed scholarly attention needs to be paid to silent stories of displacement close to home in post-war Europe to provide a more nuanced understanding of accounts of contemporary movement. We might then be in the position to not only better reflect on the messy history of displacement in Europe and to learn from past mistakes (particularly the unintentional consequences of humanitarian and care programs), but also potentially be empowered by knowledge to tear down the walls of silence present in hegemonic historical archives of key global events. Humanitarianism remains a powerful source of motivation and a legitimate point of entry for charitable and development work today (Lynch 2016:6). It is important to also understand the shadowy side of this morally potent ethos that demonstrates how humanitarianism can contribute to suffering while claiming to alleviate it (also Fassin 2007, Ticktin 2011). Silence may be the only evidence that violence is inherent in humanitarianism - or “armed love”, in Ticktin's (2011:26) words.

\section{Speak not a Word: The Many Faces of Silence}

Scholars of Italy have paid particular attention to traumatic events that occurred during World War II, focusing on divided collective memory of atrocities. The studies of Giovanni Contini (1997) and Francesca Cappelletto (2003, 2006), both in Tuscany, investigate the manner in 
which cognition and affect intersect in narratives about war. In a similar vein, Pamela Ballinger's (2002) work in the Julian March border zone between Italy and Former Yugoslavia looks at how narratives of ethnic Italians displaced in the decade after World War II only came into the public domain after the political transformations of the early 1990s. Stories of those who chose to remain in and leave the Julian March lingered in silence both at a national and community level for fifty years. In other parts of the Mediterranean anthropologists have detailed competing histories of violence and displacement, including mass child movements in late 1940s civil war Greece (Danforth and Van Boeschoten 2012) and the reconstitution of Spanish war loss memories (Aragüete-Toribio 2017). In a fascinating study that resonates with the case at hand, Jessaca Leinaweaver (2017) discusses how museum installations in Madrid direct the myth of Spanish colonial benevolence jointly toward the "pact of silence" during the Spanish Civil War and toward hospitality shown to contemporary immigrants from Latin America. The museum promotes a positive image of Spanish history, silencing certain pasts while still managing to appeal to a new immigrant audience. Many aspects of the Spanish case underline Maria's fears that the stories of today's refugees "might get lost, transformed or manipulated" by more powerful political actors. The innocence of Latin American children, Leinaweaver argues, is highlighted by the museum to frame immigration positively and endorse Spain as a civilizing force, occluding not just the violence of the colonial period but also the inequities of today's immigration.

Maria has often voiced her belief that history as recorded in school textbooks and presented at national museums is to a great extent a "cleaned-up, nicely packaged version" of complicated events. Post-war European historiography is the product of innumerable silences, omissions, and oversights. Silence requires neither a conspiracy nor even a political consensus, Trouillot (1995:106) maintains, but can be a way of complying with an accepted narrative as an 
alternative to facing a more challenging or uncomfortable truth. Individuals like Maria often remain silent about events which are drenched in dishonor, stigma, or shame.

Displacement, shame, alienation and loss can be mediated through silence which serves as a form of self-imposed amnesia (Passerini 2003:243); as Maria puts it “we couldn't speak about our experiences of relocation, my parents felt ashamed and so did we. We just had to deal with it internally". Structural, hegemonic or official silence refers to how events can be omitted from the historical record, removing conflicting details, resulting in a manipulated public narrative. Structural silence is also endorsed at the local community level as divisive events are absent from public discourse. In a comparable example from central Greece, Daniel Knight has recently shown how, owing to the abundance of controversial and shameful narratives pitting brother-against-brother, the civil war is absent from his informants' otherwise bountiful accounts of the turbulent 1940s (Knight 2015).

Silence, however, does not necessarily last forever and can be broken at a later date. Silence can "nourish a story and establish a communication to be patiently saved in periods of darkness, until it is able to come to light in a new and enriched form", facilitating time for reflection, mediation, and meaning-making for the future (Passerini 2003:238). In her emotive ethnography of Holocaust survivors and their children in Israel, Carol Kidron (2009) makes a very important contribution by analyzing silence as a mode of communication of nonpathological knowledge of traumatic events. The trauma-related silence, she argues, "may be seen as a powerful and effective conduit of memory, maintaining the imminent presence of the past in the present" rather than being a repression of past events that needs to be overcome (2009:15). Personal silence describes an individual's inability to express thoughts "from the unspeakable nature of an experience that is beyond narrative" (Kidron 2009:7). Interpretations of silence as empty and omitting information "have led to a neglect of the phenomenon of 
silence as a medium of expression, communication, and transmission of knowledge in its own right or as an alternative form of personal knowing that is not dependent on speech for its own objectification" (Kidron 2009:7).

Focusing on speech over silence detracts from part of "the complexity of the experiential world of a living human being” (Orange 2011:194). Instead we should ask,

"From whose perspective is relational knowing implicit or explicit? Surely it can only be from the perspective of the researcher/analyst, not from the perspective of the infant/patient!... 'Making the implicit explicit' raises an epistemological problem ... As Heidegger pointed out, any interpretation that makes something implicit explicit can only be from the standpoint of the interpreter's "fore-structure" (perspective, presuppositions) (Orange 2011:194-195).

Instead of obsessing with the dualism of "explicit"/ "implicit", Orange continues, we should rather pay attention to why some people "become mute ... speak compulsively and repetitively in ways that feel dead and deadening ... just scream, and others keep searching for words and expressions (Orange 2011:197).

"Embodied silence" as an existential space is enlivened in inter-subjectivity. By embodied silence I refer to the enduring felt quality of a process of interaction that is constituted in our everyday world and goes beyond language. When working with displaced people, the embodied silence is two-fold, from the side of the researcher and research participant; not a dead silence, but very active, animated and spirited, an interaction where there is an openness to vulnerability. Over multiple meetings, displaced children wrestled with the traumatic past by way of tears, through material culture or by simply sitting in silence. We spent hours in each 
other's silence, sitting under a tree gazing at the sea, contemplating a picture, just breathing, next to each other. The embodied silence on my part was a pledge of trust (see Orange 2011).

For relocated children like Maria, there was always a bodily struggle with something living within. In mourning the death of beloved friends, Derrida (2001) finds himself in a position of unspeakability, a place inside the world of facts and things (Almond 2007:44), where he is unable to articulate his feelings of loss, choosing to remain in silence. Speech, he argues, cannot do justice to the "intractable intensity" of the bodily struggle with language to express something that would resemble what has been "left living" inside of the mourner. The very shock of loss, he suggests, alters the medium in which it is registered. Silence is the only space in which to exist.

For the displaced children, even in speaking there is a silence - what is not acknowledged, that which remains outside of narrative, what exists "on the verge of articulation" but never fully realized (Derrida 2001:95). “Unspeakable” events, to employ both Derrida and Kidron's term, refer not only to an inability to articulate, but to the dehumanizing or humiliating treatment of human beings; "Even naming rape and other forms of torture only touches the edges of the unspeakable horror and degradation" (Orange 2011:197). The traces of traumatic experiences remain "at work inside a person" (Derrida 2001:94) and to speak of these episodes is to begin to acknowledge that they are no longer with us. What Derrida (2001:5-6) terms the "danger of commemoration" is an onerous task of how to situate oneself in a condition of loss; when an event is commemorated or memorialized the silence is broken and the trauma may cease (Feuchtwang 2010).

Working with people like Maria for over five years, I have come to understand how silence can be embodied in gestures repeated in a certain manner, in the way people breathe, sigh, 
avoid foods associated with periods away from their families, edit-out episodes in their lifestory, scream out during the night, whimper, stutter and sob when unable to articulate their story - what Derrida terms 'silent communication' (2001:96). While browsing her childhood photo albums, the usually vivacious and expressive Maria would sometimes pause and gaze blankly into the background of a photograph for minutes at a time, sat in silence before sighing or tutting, choking back tears, and moving on. On these occasions it was my intention not to speak for Maria, or even, as Derrida notes, to take up speech in order to give it back to her, but rather to let her occupy her silence (Derrida 2001:95). Sharing silence with the displaced is a recognition of the other's suffering, we share a moment of intersubjective pain, we hold each other.

For Maria, embodied silence is a space in the world, a habituated and learned space that has been fashioned over decades through a lack of resolution with a turbulent past, particularly the inability to discuss the relocation with parents and family. This silence is not constructed only in opposition to speech but as an onerous effort to traverse speech and as an experiential position as a result of the unresolved drama of displacement and the lack of historical recognition both within the family and wider community. There is clear interplay between her personal battles with the past and the lack of wider recognition of the relocations.

In disaster-stricken communities the displaced children of Calabria inhabit a space of silence. The unspeakable nature of the relocations was consolidated by the subsequent structural imposition by both family and society to not talk about the displacement and the distacco (separation) from the family: "Our parents did not speak about it, the village did not speak about it, we, eventually, did not speak about it either". The children's silence marks a 
perpetuation of pain for a situation without foreclosure or completion. For Maria, silence is the only rigorous response.

\section{Displacements: The 1950s Floods}

The area Grecanica, where I have conducted research since 2006, is prone to natural disasters such as earthquakes, landslides, and severe floods. Introduced in 1950 and dissolved in 1984, the Cassa per il Mezzogiorno program that aimed to stimulate economic growth and infrastructure development in South Italy was unable to remedy the environmental precarity (Martino 1979:321-322, Pipyrou 2010:24). The pursuit of economic and social mobility through emigration (transatlantic, to the European north, and internal [Minicuci 1995, Petropoulou 1997, Pipyrou 2010]) has contributed to the depopulation of area Grecanica and southern Italian peripheries at large. Water-related natural disasters that have plagued Calabria since unification have intensified local distrust in the welfare state and exposed the lack of systematic governmental attention to southern Italian peripheries. John Dickie and John Foot (2002:44) are right to argue that "the regional impact of disasters has mirrored regional cleavages in Italian society. In many ways, the southern character of certain disasters remains an area that merits further historical investigation".

In October 1951 the province of Reggio Calabria was hit by massive floods and landslides that severely damaged a considerable number of villages. The Ministry of the Interior reported that the damage affected 68 municipalities, 3,090 houses were severely damaged or destroyed, 3,797 families were hosted in temporary shanty towns and 49 people died. In October 1953 the province was once again hit by floods and landslides, the Ionian coast and inland areas were profoundly damaged with 55 people dead, dozens missing and almost 2,500 homeless. The Ufficio Provinciale dell' Assistenza Post-Bellica coordinated the evacuation of the homeless, 
placing people from the city of Reggio Calabria in barracks, abandoned local-authority housing, pavilions and school halls. Inhabitants of the area Grecanica villages of Amendolea, Galliciano, Condofuri and other small communities were transferred outside of Calabria to military camps in L'Aquila, Gaeta (both in central Italy) and Messina (Sicily) (Petropoulou 1997, Pipyrou 2016a, 2016b) where they remained for more than a year. A considerable number found employment and decided to stay in their new locations.

The end of the 1940s and the 1950s are remarkable for the conspicuous movement of people from South Italy in the name of beneficence, assistance, and solidarity. Civic groups affiliated with both the political left and the right were heavily involved in child welfare initiatives, often projecting Cold War ideologies onto their programs (Gabrielli 2005:17, Pojmann 2013). In 1946 the Unione delle Donne Italiane (Union of Italian Women, [UDI]) and the Italian Communist Party (PCI) formed the "Committee for the salvation of the children" (Comitato per la salvezza dei bambini, also, Comitato Salvezza) with the intention to save children from famine, illness, and the immediate risk of death from natural disaster (Rinaldi 2009). This humanitarian guise of political intervention was directly related to post-war public welfare initiatives and the conspicuous rise of the Italian welfare state as a "caring state" (Ferrera 1984:39, Muehlebach 2012). Political bodies on the left and right pursued projects of care and relief in the belief that such initiatives were central to building a sense of collective belonging within protective networks of care after World War II (Salvati 2001). Both sides had their own version of how to frame interventions and the premises on which to base the hierarchy of the "politics of life" - which lives were selected to be saved (Fassin 2007:500-501, 2010:241). For the left, the humanitarian efforts were based on the ideals of family and working-class solidarity, for the center-right, emphasis was placed on Catholic ideals of care, generosity and 
charity. As such, the interventions, although often provoked by natural and social disasters, were overtly projects of future-building by the political bodies involved.

Owing to the consequences of natural disasters, the UDI and PCI took the initiative during the 1950s to relocate children aged 3-12 from southern Italy to live with new families in the north. .ii $^{\text {ii }}$ Center-right newspapers at the time condemned the scheme as an "abduction of infancy" (Berlinguer 1980:5). Intervention by the Church and police, who openly opposed the relocations by the Left, led to the removed children being sent to monasteries, orphanages or juvenile detention centers instead of making the move to new families in the north ( $L$ 'Unità 23/12/51). The scheme of mass youth relocation by the PCI and UDI was not an isolated incident. During the same years and for similar reasons the government and Church also relocated orphans or children from very poor families. The Ente Nazionale per la Protezione Morale del Fanciulo (National Agency for the Moral Protection of Children) was the primary government post-war agency dealing with the assistenza all' infanzia (assistance to childhood).

Female civic associations (associazionifemminili) across the political and social spectrum were directly involved in child displacement initiatives during the Cold War (Gabrielli 2005:17, Pojmann 2013:46). ${ }^{\text {iv }}$ As well as UDI, the Centro Italiano Femminile (Italian Women's Center $[\mathrm{CIF}])$, associated with the Church and the Christian-Democrat party, also played a key role in the relocations (Rodano 2010:27). After World War II, Cold War ideologies permeated the national women's associations, influencing their approaches to international issues of gender, womanhood and child protection. UDI tended to view Communist states, especially the USSR, as open to women's emancipation, pointing to the careers and opportunities for women in Russia in comparison to Italy. With the support of the Women's International Democratic Federation (36 million members) UDI launched a pro-Soviet propaganda campaign to show 
women in Italy how socialism and communism could offer a better future. On the contrary, CIF looked to the suburban American housewife as the model of womanhood, especially favoring international programs and projects that benefited stay-at-home mothers with children. CIF became active in the World Movement of Mothers, a conglomeration of similar organizations from thirty countries worldwide. The Italian women's associations made international alliances based on Cold War constructs, but they remained particularly committed to the interests of women in Italy (Pojmann 2013).

\section{Bandiera Rossa (Red Flag): Leftist Relocations}

The 1950s child relocations in Calabria by the Communist Party of Italy and UDI, were directly associated with the ideology and solidarity found within the Italian working classes dating back to the years of wartime resistance (Minella, Spano and Terranova 1980:13). The Communist party played a fundamental role in the movement of children based on the hope that Italy could be reborn within ideals of solidarity (solidarietà). During the Cold War in Italy, the ChristianDemocrats depicted the Russian child as "figlio snaturato" (unnatural son), and accused the PCI of a calculated plot to create "unnatural" generations of people who denounced their families and turned against their mothers and fathers (Pivato 2015:126).

The anti-Communist Italian press reflected on events in Greece where almost 20,000 children were evacuated by the Communists during the civil war, warning Italian parents, often through graphic visual images, that " $i$ communisti mangiano $i$ bambini" (the communists eat the babies) (Pivato 2015). Following the 1951 and 1953 alluvioni, children from Reggio Calabria and area Grecanica were transferred by UDI to communist families primarily residing in Rome. ${ }^{\mathrm{v}}$ In some cases parents consented to the transfer as a sign of solidarity with their party, a contribution to the moral community governing their politics of life (Fassin 2007:501, 
2010:xii) rather than out of need for humanitarian aid. While some displaced children have spoken poignantly of the effects of separation and loss, including instances of abuse, neglect and trauma, others have defended their experience of the movements claiming that they were offered better life prospects. Others have remained completely silent, refusing to talk about their experience, keeping their stories secret even from their own children. Regardless, there remains a structural silence at the level of the local community and official history - the relocations are not prominent in hegemonic accounts of the era and there is little local discourse on the events. Although some of the children frame their experiences in a positive light, only a small minority talk of their time away from their families and often continue to repeat the Party line of the relocations being an important demonstration of working-class solidarity. At the levels of local community and institutionalized history, the leftist relocations remain shrouded in silence.

In the alluvione of 1951 Mario was eight years old. He left his village in the Aspromonte mountains with his two brothers in cars belonging to the Communist party and lived with a family in Naples for six months. Mario remembers:

We were not flooded. We had no property. The alluvione hit people who had land or houses in the lower part of the area. Here in our village there was an important section of the Communist party. Also, my uncle was a communist of strong convictions, one of the founders of the section, politically very intelligent ... For my parents, it was not easy to send away three children, but they had to obey the party. Other families sent their children either because they were in real need or because they obeyed the party. I remember this caravan of cars that went to the city of Reggio Calabria, stopping in all the villages along the Ionian coast. After a point the police stopped us and we were put 
in police vans. Then the police took us to Messina to a convent near the sea. We had bad days there, ugly ... because they were not organized. The memory is so terrible ... bad ... I assure you that with the passing years my head must have drawn it up into an even more negative image, but I remember that it was bad ...

One night we spent in the Reggio Calabria city Chamber of Labor. Back then I was a beautiful child, there was a family who wanted to adopt me and took me home for the night because they thought that we were orphans, because no one knew, our status was not clear ... Over the following years I tried to find the family, I knew their name, I imagine that they were disappointed that they couldn't keep me ... I slept one night in their house ... I may remember the police on the road escorting us but I have fragmented memories ...

We then left Reggio Calabria for two destinations: Naples and Rome. We took the 8pm train, there was my mum, me with my brother, my cousin, we were about ten people, there could be no danger. I remember that we arrived in Naples in the morning with the historic train which we called the "Roman", connecting Reggio Calabria to Rome, arriving in Naples at 5am. My brother and I were placed separately with the families of two brothers, highly regarded by the Communist Party. Naples in the 1950s, it may seem strange, had a more solid economic structure than today. The family of the brothers had a shoe factory with fifty workers. Their house was modest ... They had no children ... even there the same problem (implying that they wanted to adopt him) because they cared so much, had done so much for me, it was painful .... My mum did not want to ... my father was, like, well, there are possibilities ... but mothers are more 
I called the couple that hosted me uncle and aunty, two wonderful people, among the kindest people I've met in my life! The first thing they did was to bathe me, because we came from a part of the country without running water in our homes. My memory of this bath was beautiful. Beautiful, because I was doing it every week! I was not used to it ... I said ironically "do I have to bathe again?" Immediately after, they took me to a shop to get dressed. You see in the picture with my brother, I was completely changed, I had beautiful clothes, the Sicilian cloth cap, a coat ... for me it was an exceptional thing, they were happy because they had no children. I came across extraordinary things in Naples: for the first time I saw a big city, a tram ... Back in the village there was a cinema, but in Naples I saw my first color film! I remember the film "Toto in color" at the Met, the largest theatre in Naples. I get emotional every time I see it again, and my wife cannot understand why ...

I had a bit of contact with my brother and we used to see each other. He did not have my luck ... the family I was living with sent me to a good school where I learned a bit of Italian (until then he was speaking the Calabrian dialect). We remained in Naples for about six months. When we returned to the village the local communists put me on top of a table in front of the Chamber of Labor's office. I was dressed nicely and they asked me to say a few words. They were doing propaganda - look, this is what we are!

Mario is involved with the Communist party to this day but reflecting back he recognises that for many parents it was not easy to send their children away but they had to "obey the party" in solidarity, "This is what they believed was best for our future ... our collective future ... to show solidarity with others with the same (political) background". Despite being separated 
from his siblings, the experience was generally positive and he says that he was given opportunities for a better life that were not available in his Calabrian village; this was not the case for his brother. Although Mario is one of the few who can articulate his experience of displacement, the case of the Communist relocations, to a great extent, remains silenced on a communal level and in the historical archives. Even Communist-supporting residents of the same village do not know who else from their immediate community was relocated. The shame of being 'victims of floods', broken family ties, and failures in the 1950s internal political struggles are strong reasons why people displaced by the Left continue to avoid the topic.

Another child relocated by the Communist party, Toto was evacuated after the alluvione of 1951, when he was 6 years old. He went to live with a family in Rome. His father was secretary of the Communist Party and the Chamber of Labor in their village in area Grecanica. His father played a central role in organizing the local operation to relocate children to Communist families in central Italy, helping convince people to send their children away by presenting the humanitarian initiative in terms of solidarity. Toto remembers his father encouraging people by saying "send it!" (mandalo!). Toto arrived in Rome by train. At the station there were local communist families and according to the size of their home, how many children they already had, and their economic position, they selected one or two children off the train. The children were traveling without documents. Toto was so happy in his new family in Rome that he asked his father to leave him there. His request was declined. In his narrative Toto places special emphasis on the opportunities for education, culture, and affection that he received from the family. It was there that he learned to kiss the family goodnight and hug them regularly - a habit that he lost again when he returned to the village six months later. 
The above stories of children relocated by the Communists do not generally tell of traumatic experiences but are emblematic of a type of displacement mobilized under principles of solidarity. Regardless of "need", families involved with the Communist Party sent their children away to set an example and to convince others that their children would have a brighter future away from Calabria. Parents, particularly mothers, are often portrayed as opposing the relocation of their children, but ultimately succumbed to the will of their husbands. This operation is exemplary of the future-building project carried-out by the Communist Party, cultivated through assistance and solidarity.

What is remarkable about the Communist relocations, especially given the relatively positive narratives provided by those able to recount, is that nobody in Calabria officially involved with the PCI and UDI could provide detail about the event. In some cases, research participants had only vaguely heard of the child relocations by PCI and UDI and Toto and Mario were two of the very few relocated children from the Communist side who spoke openly about their experiences. The communists were not victorious in the immediate post-war Italian politics (see Pavone 2014) and only recently have the relocated children - now in their late 60s and early 70 s - felt that they had space to reflect on their experiences. Like many other post-war European nations scarred by political schisms between the left and the right, the process of producing hegemonic accounts of the past that are universally palatable and promote national harmony have filtered out the stories of the child relocations, no matter if these experiences were transformatively positive or negative (cf. Danforth and van Boeschoten 2012). In this vein, the Communist relocations remain silenced in both community accounts of the past and in Italian historiography.

\section{Tears for Fears: The Story From the Other Side}


I first met Giovanni over four years ago. It was an overcast day with the imminent threat of rain in the air. I visited him in his village in area Grecanica after having made phone contact to explain my desire to talk to him as part of my project. Giovanni is the older brother of Maria, the woman featured in the opening vignette. They were both displaced after the alluvione of 1953. They were seven and six years old respectively when they were moved to different Church institutions in Sicily by the Italian Red Cross. Unaware that they would be leaving, the children were collected while playing in the fields near their home, only stopping briefly to wave goodbye to their parents. They left home in October 1953 and returned back at Christmas 1954. When in Sicily they were separated and lived in gender-segregated institutions Giovanni was sent to the north of Italy and Maria stayed in Sicily. Similar to many alluvionati (flood victims), their parents had applied for government assistance based on 'objective criteria' of damage; subsidies available to flood victims, for aid and a new home. The children insist that their parents were unaware that this application involved the transfer of their children. It is through this list, they argue, that the Red Cross found their names and moved them to separate Church-sponsored institutions.

For both children, life in the institutions was hard. The hunger they experienced in these collegii, the malnutrition, the stale bread, the corporeal punishment was unprecedented, something they could never have imagined. When Giovanni sees reports on television about nurseries where children are tortured, he recalls the agonies he lived through, engrained on his body. While at the institution, he sent a photo to his parents but the writing on the back was not his. He only passed the first elementary grade when he was nine after he had returned to his village. "I was suffering, I could have never written, 'I am having fun, I am fine'. They asked someone else to write it, probably a boy older than me". 
Equally, Maria remembers that when she and her friend Anna were suffering in the collegio, they were making escape plans.

We were still children, six years old, we knew that we had been taken to somewhere in Sicily but we did not know where. With my friend Anna I fabricated these escape plans, when I see film stories like mine, I know that they are true. I remember during Christmas they put us in a queue to give us a cake each. As you do today with the immigrants that reach Italy. I have done that with the immigrants. I empathize with the immigrants.

Upon their return, many children like Giovanni and Maria remained silent about their experience. They soon understood that what had happened caused a great deal of suffering to their parents. Their mother insisted that they never applied to send their children to the collegio. Their father could neither imagine nor accept the experience of his children. For him, they maintain, it was a source of constant humiliation to think that his children had been sent away and endured such tortures. According to Giovanni and Maria, their parents were victims of false promises by the government to provide them with subsidies and a new house; things which never materialized. The Red Cross was partly implicated in this game, Maria insists, "It was all a huge 'magna, magna' eat, eat (Calabrian dialect, from Italian mangia, implying corruption). Do you understand?" When speaking to Giovanni and Maria about their childhood experiences, both independently expressed surprise to learn that the communist associations also relocated children after the 1950s landslides, which emphasizes how the events have been silenced on both national and local levels. Indeed, in the same small coastal village, children who were relocated are to this day rarely aware of others who suffered the same fate, even if they now reside just a few houses apart. 
After returning to their village during the final days of 1954, children only occasionally talked between themselves when alone. Maria says "we were just kids; we did not know how to defend ourselves. My father asked me why I did not let him know that I suffered when he visited me in the collegio. But when I told him later, he did not want to know. I always remember Elizabeta, our horrible teacher; I would sometimes mention her name. It was not out of fear that we did not speak to our parents about what happened but because we did not want to make them suffer". Suddenly Maria pauses for a while.

You know what happened? For me ... I was introverted and never spoke about that. The fact that I went to the collegio was shameful, humiliating. I never discussed that, not even with the rest of the village children who might have had the same fate. Because for me to say that I was a girl alluvionata and that I was sent away was hard ... I had been through so much it was something that I would never speak about. It was something that had to stay with us, stay within. I also felt sorry for my parents, poor things. I was thinking, why did they do this to us, they were so attached to us? With Giovanni we found refuge in each other's confidence to maybe discuss our suffering. But we never spoke to our parents or other people. We kept it within us.

I have been working with Giovanni and Maria for over five years, but my mind always goes back to our first encounter. I went to interview Giovanni and Maria and found myself in a room with the whole family - Maria's husband, Giovanni's wife, siblings, children, son-in-law, nieces, and nephews. The family was not aware of all the details of the relocations, but Giovanni and Maria had recently started communicating snippets of their experiences to trusted family members. They had occupied their silence for over sixty years. As the conversation 
progressed Maria became more extroverted in vocalizing her memories of life in the institution - she later mentioned that an academic provided a legitimate license for her to tell her story. Giovanni sat in silence. He gradually fell back into his chair, his eyes becoming redder and redder. I could see his bodily struggle with language, clenching his fists so hard that his hands began to turn white. The more his sister spoke, the deeper Giovanni fell into silence. Until he burst into tears. I gave him a hug, myself by now also in tears. Little was I to know that this scene would be repeated frequently in our future encounters. Tears are a tried and tested part of our relationship. His persona changes when we talk about his relocation, his body is hunched and quivers, he cuts a pale and broken figure. His experiential position transverses speech as he lives the relocations in a space of silence while - to paraphrase Derrida - the traumatic experiences remain at work inside him.

I always go back to that first encounter with them because Giovanni's tears were a puzzle to me then. From a methodological perspective, his tears confirmed that the interview is more than an exchange of words, for we were watching each other while his sister commanded the conversation. Our exchange of gaze and tears was the moment when I had the chance to begin to understand how displaced children like Giovanni lived all these years with the suffering and the silence. His is an embodied silence attached to a wider structure of unspoken events. Enlivened in inter-subjectivity, Giovanni's repetitive tears are full of information about a personal knowing of the violence of humanitarianism and care which go beyond narrative.

\section{Conclusions}

With the political dominance of the Christian-Democrats at the end of 1940s and the 1950s, non-state humanitarian initiatives where severely impeded, with media of the era mentioning an attempt by the government to "monopolize assistance" in disaster relief in the era of welfare 
and state-building (L'Unità 16/2/52). The period was characterized by mass child relocations with numerous bodies competing to own the narrative of the next generation - who will be their savior, who will own the narrative of the "pathos of assistance" (Fassin 2010:ix)? For the left, the humanitarian efforts were linked to visions of Italy being reborn in ideologies of the family and working-class solidarity. In an attempt to realize these dreams, children, even those not directly impacted by the floods, were relocated to live with communist families elsewhere in Italy. For the Center-right, humanitarianism was integral to a wider rhetoric of "the caring state" that extended a benevolent hand to deserving citizens, with overtones of Catholic charity. Remarkably, given the number of children involved and the political stakes, the tumultuous population movements of this era are not a salient part of official history and are not discussed openly in local communities affected by the relocations. The silence is two-fold, both structural and embodied, cloaking the entire political spectrum. The violence of humanitarianism produced a divisive narrative that needed to be concealed or written-out of history, while individuals continued to live within a space of silence as the most predominant way of dealing with their experiences.

Overarching ideologies of society and family, especially in relation to an idealized imagined or proposed future, are pertinent in the reasoning of humanitarian assistance; the state intervenes, shapes and replaces family via claims to the common good or for the benefit of vulnerable individuals. Benevolence and compassion are central to the politics of care enacted under the threat of emergency (Ticktin 2011:3) and in the case of the children, it is interesting that alongside the state, forces that defined themselves as progressive, such as women's civic groups, equally took on the task of intervening with a vision of protecting the vulnerable, claiming a better future for the children and for society at large, even though this often entailed the dismantling of families. At a time when the Italian state was concentrating on developing 
a viable post-war welfare system, the initiatives to relocate children after natural disasters played into the rhetoric of care and assistance that was dominant across the political spectrum (Ipsen 2006). Although perhaps well-intentioned, the relocations did serve political purposes and were undeniably violent.

The violence of humanitarianism in the post-war years continues to shape how people understand displacement in contemporary Europe. For my Calabrian research participants, the layers of silence that surround the 1950 s relocations have led to a bodily struggle with something "left living inside" (Derrida 2001:95). This embodied silence as existential condition is interrelated with the wider structural societal silences in the immediate family, community, and national historiography. Silence has become a habituated and learned space, shaped over the course of more than sixty years. A focus on the multi-layered conditions of silence - what Derrida refers to as "traversing speech" - opens "the complexity of the experiential world of a living human being" (Orange 2011:194). Silence is not necessarily a result of trauma (though it may be) and is not always opposed to speech (though sometimes is). It is a position that my research participants occupy in the world that can only be captured through long-term ethnographic engagement, through sharing in the inter-subjectivity of their silence.

Recollecting tragedy is a difficult, often conflictual process marked by repression and forgetting (for instance, Bevilacqua 1981:13). Silencing, as Trouillot argued, is a structuring process, often quite violent, by which particular histories, deliberately or not, have escaped archiving. Silenced stories may slip between the cracks and crevices of history and can be found outside of the "corpus" of a handful of narrations that ultimately define hegemonic historiography (Trouillot 1997, Knight and Stewart 2016). Yet, the interrogation of the 
powerful forces of silence cannot remain focused on the past; hence my concern that we learn from silenced European pasts when confronting current so-called "unprecedented" events such as the migration crisis that so poignantly occupies the minds of my research participants. As Trouillot (1997:150) cautions, "the focus on the past often diverts us from the present injustices for which previous generations only set the foundations". Could child displacement be regarded as a burden that Italy could not or was not willing to shoulder after the moral and political defeat of the war? As I have argued here, silence should be traced within the context and legacies of the first two decades of the Cold War in Italy, the building of the post-war collective consciousness, and the competition over owning the future generation of Italian citizens.

Despite being scarce and hard to come-by, individual accounts of the 1950s child relocations are representative of the complex power-games and the violence of humanitarian initiatives. The archiving and re-making of history takes place according to particular personal and political agendas. In their articulations, mis-articulations, and tears, my research participants remarkably echo the historian Tony Judt (2005:10) who has argued that after the devastating schisms of World War II, silence in Europe seemed like a natural condition. In other parts of their narratives they echo Alessandro Portelli (1981) who noted that very often life takes over and there is no time for mourning. For all my research participants, life indeed took over. Poverty, marriages, migrations, lost relatives, dead children. As part of my methodology I asked Giovanni to write his story on his own terms. It took him five months to write a fivepage narrative which was very often interrupted by floods of tears. His narrative entitled "una storia chiusa in un cassetto" (A story locked in a drawer) ends as follows: "This is the story that I kept in a drawer jealously preserved, reliving it alone in my thoughts provoking within 
me very strong emotions. Up to now I kept it hidden in my heart, I never talked about this, not even with my daughters ... it is now time to narrate".

\section{References}

Almond, N. 2007. The New Orientalists: Postmodern Representations of Islam from Foucault to Baudrillard. London: I.B. Tauris.

Aragüete-Toribio, Z. 2017. Confronting a history of war loss in a Spanish family archive. History and Anthropology 28(2): 211-234.

Ballinger, P. 2002. History in Exile: Memory and Identity at the Borders of the Balkans. Princeton, NJ: Princeton University Press.

Barnett, M. 2011. Empire of Humanity: A History of Humanitarianism. Ithaca: Cornell University Press.

Berlinguer, 1980. Prefazione. In Cari bambini, vi aspettiamo con gioia.... il movimento di solidarietà popolare per la salvezza dell'infanzia negli anni del dopoguerra, edited by A. Minella, N. Spano, and F. Terranova. Rome: Teti.

Bevilacqua, P. 1981. Catastrofi, continuità, rotture nella storia del Mezzogiorno. Laboratorio Politico (5-6): 177-219.

Bhabha, J. 2014. Child Migration and Human Rights in a Global Age. Princeton: Princeton University Press. 
Buffardi, G. 2010. Quel treno lungo: Il 'Comitato per la salvezza dei bambini di Napoli’ 19461947. Naples: Dante and Descartes.

Cappelletto, F. 2003. Long-Term Memory of Extreme Events: From Autobiography to History. Journal of the Royal Anthropological Institute 9(2): 241-260.

Cappelletto, F. 2006. Social Relations and War Remembrance: Second World War Atrocities in Rural Tuscan Villages. History and Anthropology 17(3): 245-266.

Cohen, G. D. 2011. The "Human Rights Revolution" at Work: Displaced Persons in Postwar Europe. In Human Rights in the Twentieth Century, edited by S-L Hoffman. Cambridge: Cambridge University Press.

Cohen, G. D. 2012. In War's Wake: Europe's Displaced Persons in the Postwar Order. Oxford: Oxford University Press.

Contini, G. 1997. La Memoria Divisa. Roma: Rizzoli.

Danforth, D. and R. Van Boeschoten. 2012. Children of the Greek Civil War: Refugees and the Politics of Memory. Chicago: University of Chicago Press.

de Waal, A. 1997. Famine Crimes: Politics and the Disaster Relief Industry in Africa. London: Africa Rights. 
Derrida, J. 2001. The Work of Mourning. Chicago: University of Chicago Press.

Dickie, J. and J. Foot 2002. Introduction. In Disastro! Disasters in Italy since 1860, edited by J. Dickie, J. Foot and F. Snowden, 3-60. New York: Palgrave Macmillan.

Fassin, D. 2007. Humanitarianism as a Politics of Life. Public Culture 19(3): 499-520.

Fassin, D. 2010. Humanitarian Reason: A Moral History of the Present. Berkley: University of California Press.

Fassin, D. and M. Pandolfi. (eds). 2010. Contemporary States of Emergency: The Politics of Military and Humanitarian Interventions. New York: Zone Books.

Faubion, J. 1993. Modern Greek Lessons: A Primer in Historical Constructivism. Princeton: Princeton University Press.

Feuchtwang, S. 2010. The Transmission of Traumatic Loss: A Case Study in Taiwan. In Remembering Violence: Anthropological Perspectives on Intergenerational Transmission, edited by Argenti, N. and K. Schramm. Oxford: Berghahn.

Ferrera, M. 1984. Il Welfare State in Italia: Sviluppo e crisi in prospettiva comparata. Bologna: Il Mulino. 
Fitzgerald, R. 2001. Clinical Christianity: The Emergence of Medical Work as a Missionary Strategy in Colonial India, 1800-1914. In Health, Medicine and Empire: Perspectives on Colonial India. Edited by Pati, B. and M. Harrison. Hyderabad: Orient Longman. pp: 88-136.

Gabrielli, P. 2005. La Pace e la Mimosa: L’Unione donne italiane e la costruzione politica della memoria (1944-1955). Roma: Donzelli.

Gatrell, P. 2011. Free World? The Campaign to Save the World's Refugees 1956-1963. Cambridge: Cambridge University Press.

Gatrell, P. 2013. The Making of the Modern Refugee. Oxford: Oxford University Press.

Gundle, S. 2000. Between Hollywood and Moscow: The Italian Communists and the Challenge of Mass Culture 1943-1991. Durham: Duke University Press.

Haskell, T. 1985. Capitalism and the Origins of the Humanitarian Sensibility. The American Historical Review 90(3-4): 339-361, 547-566.

Hirschon, R. 1989. Heirs to the Greek Catastrophe: The Social Life of Asia Minor Refugees in Piraeus. Oxford: Berghahn.

Holian, A. 2011. Between National Socialism and Soviet Communism: Displaced Persons in Postwar Germany. Michigan: University of Michigan Press. 
Ipsen, C. 2006. Italy in the age of Pinocchio: Children and Danger in the Liberal Era. New York: Palgrave.

Judt, T. 2005. Postwar: A History of Europe since 1945. London: Vintage Books.

Kidron, C. 2009. Toward an Ethnography of Silence: The Lived Presence of the Past in the Everyday Life of Holocaust Trauma Survivors and Their Descendants in Israel. Current Anthropology 50 (1): 5-27.

Knight, D. M. 2015. History, Time, and Economic Crisis in Central Greece. New York: Palgrave.

Knight, D. M. and C. Stewart. 2016. Ethnographies of Austerity: Temporality, Crisis and Affect in Southern Europe. History and Anthropology 27(1): 1-18.

Leinaweaver, J. 2017. Transatlantic unity on display: the "white legend" and the "pact of silence" in Madrid's Museum of the Americas. History and Anthropology 28(1): 39-57.

Lynch, G. 2016. Remembering Child Migration: Faith, Nation-Building and the Wounds of Charity. London: Bloomsbury.

Malkki, L. 1995. Purity and Exile: Violence, Memory and National Cosmology Among Hutu Refugees in Tanzania. Chicago: University of Chicago Press. 
Martino, P. 1979. L'isola grecanica dell'Aspromonte. Aspetti sociolinguistici. In I Dialetti e le Lingue delle Minoranze di Fronte all'Italiano, edited by F. Albano Leoni, 305-341. Roma: Bulzoni.

Minella, A., N. Spano, and F. Terranova. 1980. Cari bambini, vi aspettiamo con gioia .... il movimento di solidarietà popolare per la salvezza dell'infanzia negli anni del dopoguerra. Rome: Teti.

Minicuci, M. 1995. Time and Memory: Two Villages in Calabria. In Time: Histories and Ethnologies, edited by D. O. Hughes and T. R. Trautmann, 71-104. Michigan: University of Michigan.

Minn, P. 2007. Toward an Anthropology of Humanitarianism. The Journal of Humanitarian Assistance: Field Experience and Current Research on Humanitarian Action and Policy. Online entry August $6^{\text {th }} 2007$, accessed $4^{\text {th }}$ June 2019.

Moe, N. 2006. The View from Vesuvius: Italian Culture and the Southern Question. Berkeley: University of California Press.

Mosse, D. 2005. Cultivating Development: An Ethnography of Aid Policy and Practice. London: Pluto Press.

Muehlebach, A. 2012. The Moral Neoliberal: Welfare and Citizenship in Italy. Chicago: Chicago University Press. 
Orange, D. 2011. Speaking the Unspeakable: The implicit, traumatic living memory and the dialogue of metaphors. International Journal of Psychoanalytic Self Psychology 6(2): 187-206.

Passerini, L. 2003. Memories between Silence and Oblivion. In Contested Pasts: The Politics of Memory, edited by K. Hodgkin and S. Radstone. London: Routledge.

Pavone, C. 2014. A Civil War: A history of the Italian resistance. London: Verso.

Pentzopoulos, D. 1962. The Balkan Exchange of Minorities and Its Impact on Greece. London: C. Hurst and Co.

Petropoulou, C. 1997. Mnimi, Syggeneia, Tautotita s'ena Ellinofono xorio tis Kalavrias (Galliciano). Diss., Thesis, Faculty of History and Archaeology, Department of Modern and Contemporary History, Folklore and Social Anthropology, Aristotle University of Thessaloniki.

Pipyrou, S. 2010. Urbanities: Grecanici Migration to the City of Reggio Calabria, South Italy. History and Anthropology 21(1): 19-36.

Pipyrou, S. 2014. Colonialism and Southernisation: The Case of the Grecanici in Calabria. Etnografia e Ricerca Qualitativa, Special Issue, 'New Ethnographic Studies on Italy's Southern Question(s)', Number 2, pp: 245-263

Pipyrou, S. 2016a. The Grecanici of Southern Italy: Governance, Violence, and Minority Politics. Philadelphia: University of Pennsylvania Press. 
Pipyrou, S. 2016b. Adrift in Time: Lived and Silenced Pasts in Calabria, South Italy. History and Anthropology 27(1): 45-59.

Pivato, S. 2015. I Comunisti Mangiano i Bambini: Storia di una Leggenda. Bologna: Il Mulino.

Pojmann, W. 2013. Italian Women and International Cold War Politics, 1944-1968. New York: Fordham University Press.

Portelli, A. 1981. On the Peculiarities of Oral History. History Workshop. A Journal of Social Historians 12 (Autumn 1981): 96-107.

Quine, M. S. 2002. Italy's Social Revolution: Charity and welfare from liberalism to fascism. New York: Palgrave.

Rinaldi, R. 2009. I Treni della Felicità: Storie di Bambini in Viaggio tra due Italie. Roma: Ediesse.

Rodano, M. 2010. Memorie di un che c'era. Milano: Il Saggiatore.

Rozario, K. 2003. Delicious Horrors: Mass Culture, The Red Cross, and the Appeal of Modern American Humanitarianism. American Quarterly 55(3): 417-455.

Salvati, M. 2001. Behind the Cold War: Rethinking the Left, the State, and Civil Society (1940s-1970s). Journal of Modern Italian Studies 8(4): 556-77. 
Salvatici, S. 2018. Fighters without Guns: Humanitarianism and Military Action in the Aftermath of the Second World War. European Review of History 25(6): 957-976.

Samuel, R. 1990. History, The Nation, and Schools. History Workshop Journal 30(1): 75-80.

Schneider, J. (ed.). 1998. Italy's 'Southern Question': Orientalism in One Country. Oxford: Berg.

Teti, V. 2004. Il Senso dei Luoghi: Memoria e Storia dei Paesi Abbandonati. Roma: Donzelli.

Ticktin, M. 2006. Where Ethics and Politics Meet: The Violence of Humanitarianism in France. American Ethnologist 33(1): 33-49.

Ticktin, M. 2011. Casualties of Care: Immigration and the Politics of Humanitarianism in France. Berkley: University of California Press.

Trouillot, M-R. 1995. Silencing the Past: Power and the Production of History. Boston, MA: Beacon Press.

Trouillot, M-R. 1997. Silencing the Past: Layers of Meaning in the Haitian Revolution. In Between History and Histories: The Making of Silences and Commemorations, edited by G. Sider and G. Smith. Toronto: University of Toronto Press. 
Winichakul, T. 2002. Remembering/ Silencing the Traumatic Past: The Ambivalent Memories of the October 1976 Massacre in Bangkok. In Cultural Crisis and Social Memory: Modernity and Identity in Thailand and Laos, edited by Keyes, C. F. and S. Tanabe. London: Routledge.

Zahra, T. 2011. The Lost Children: Reconstructing Europe's Families after World War II.

Cambridge, MA: Harvard University Press.

\footnotetext{
' Historians of displacement and humanitarianism have noted that population movements are often branded as 'unprecedented'. Cases during the dismantling of the Ottoman Empire and the exchange of populations between Turkey and Greece in 1923 are evocative. The Lausanne Treaty stipulated the terms of exchange under which 2 million Christians and Muslims crossed the national borders of Greece and Turkey. Greece, with a population of 5.5 million, received 1.3 million refugees from Anatolia. Such was the scale that media, politicians and historians of the time characterised the movement as 'unprecedented' (Hirschon 1989, Pentzopoulos 1962). Since the beginning of World War II, it is estimated that almost 30 million people have been transplanted or uprooted in Europe (Cohen 2012:4). As the Director of the Refugee Studies Centre at Oxford University, Alexander Betts, argues, "The crisis that took hold in 2015 was not a crisis of numbers. It was a crisis of politics" (https://www.rsc.ox.ac.uk/news/alexander-betts-discusses-refugee-empowerment-at-the-aurora-dialogues).

ii For a discussion of how history is constructed through its presentation in school textbooks, as well as by trends in the education sector, see Samuel (1990) and Faubion (1993).

iii There were numerous notable occasions of child relocation in Italy before the middle of the twentieth century. For instance, the movement of children after the Messina-Reggio Calabria earthquake of 1908, child displacement under the fascist regime of the 1920s, the PCl relocation of impoverished children from Naples in the late 1940s, and the movement of the sons and daughters of imprisoned agriculturalists in San Severo, Puglia, in 1948-49 (see, for instance, Minella and Spano 1980, Rinaldi 2009, Buffardi 2010). See also the film 'Pasta Nera' (directed by Allesandro Piva, 2011).

iv On the activities of $\mathrm{PCl}$ affiliated organisations in the mid-late twentieth century, see Gundle (2000).

${ }^{\vee}$ In her book Memorie di un che c'era, Marisa Rodano (2010:72) mentions 400 children being relocated to Rome after the 1951 landslides.
} 